\title{
Decentralisation and Governance of the Education System in Mexico
}

\section{Mauricio Covarrubias Moreno" \\ Adriana Plasencia Díaz \\ Mauricio Covarrubias Romero ${ }^{* * *}$}

UDK

37.014.552:35.071.6(72)

$35.071 .6(72)$

Review scientific paper / pregledni znanstveni rad

Received / primljeno: 8. 6. 2015.

Accepted / prihvaćeno: 20. 7. 2016.

The purpose of this paper is to present an overview of the progress of a little more than two decades of political decentralisation in Mexico, through so-called educational federalism. The Agreement for the Modernisation of Basic Education in 1992 was a turning point in the history of education in Mexico, because it represented the first attempt at comprehensive reform in the sense that, in addition to curricular reform and promotion of social participation, it comprised the overall redesign of the organisation and management of the education system. Our analysis aims

${ }^{*}$ Mauricio Covarrubias Moreno, Ph.D., Professor of Public Administration at the National Autonomous University of Mexico (profesor javne uprave Nacionalnog Autonomnog Sveučilišta Meksika, e-mail: mauri1324@hotmail.com)

${ }^{* *}$ Adriana Plasencia Díaz, Ph.D., Professor at the National Institute of Public Administration of Mexico (profesorica Nacionalnog instituta za javnu upravu Meksika, e-mail: adrianaplasencia@hotmail.com)

****Mauricio Covarrubias Romero (e-mail: mau_covas@hotmail.com) 
to show the dislocation suffered by the national education policy due to the lack of coordination between the actions of different levels of government. We do not intend to argue against federalism as a system of political organisation, but to draw attention to the concrete experience of educational decentralisation in Mexico, and how the advantages of decentralisation can be undermined by shortcomings in its design and implementation.

Keywords: decentralisation, educational federalism, comprehensive reform, social participation, education system, coordination

\section{Introduction}

The purpose of this article is to analyse Mexican education policy after the signing of the Agreement for the Modernisation of Basic Education in 1992, which is a benchmark in the history of education in Mexico. It represents the first attempt at complete reform in the sense that, in addition to curricular reform, a re-evaluation of the teaching function and increased social participation, it comprises a general reappraisal of the organisation and management of the education system.

It starts with the assumption that the decentralisation model, or educational federalism, which was established by the National Agreement has affected the governance of the education system as a whole, and in particular, the carrying capacity of the Ministry of Education as the national authority responsible for setting objectives, strategies, and lines of action of education policy, measuring results, and compensating for differences. In other words, the responsibility to direct the education system towards the goal of providing quality education for all belongs to the federal authority.

To define the subject matter, we note that among the many factors that affect the governance of the education system, our analysis aims to show the dislocation suffered by the national education policy due to a lack of coordination between the actions and levels of government, made manifest by decentralisation. In no way does it seek to argue against federalism as a system of political organisation, but to draw attention to the concrete experience of education called Federalism in Mexico, and how the advan- 
tages of decentralisation can be undermined by shortcomings in its design and implementation.

To this end, the paper is divided into five sections. In the second, the governance of the education system is proposed as a theoretical, political, and practical problem. In the third, the meaning of the notion of national education policy in the context of the existing decentralised model, known as educational federalism, is explored. The fourth section documents the problems of articulating an education policy in federalism. The fifth section differentiates between the Education Sector Programs and the National Policy on Education. Finally, conclusions are presented.

\section{The Governance of the Education System}

After two decades of implementing education system reforms in several Latin American countries, we are able to raise the issue of governance of the education system as a theoretical, political, and practical problem. However, since it does not operate in a vacuum, it is necessary to first place the subject in the context of governance problems that affect society as a whole.

Today the task of government involves complex configurations and interactions both within the public administration, and between the public administration and its environment, through a variety of connections that mark the passing of important government policies and programs. Public issues have become terms of size, strength, and connectivity. A larger territory and greater population result in the involvement of more relevant factors and an accumulation of effects. We can say that the expansion in the scale of the phenomena also reflects an increase in the scale at which decisions (Covarrubias, 2008) should be taken.

The complexity of states, indicates Claus Offe, more than of other types of organisations, undermines organic integrity and consistency. The notion of "decomposition of state power by an increase of functions" says that the ability of the complex state to make rational decisions is explained by the fact that the multiplication of responsibilities is accompanied by increased instances, authorities, and administrative agents involved. For Offe, this produces an internal diversification and fragmentation of departmental perspectives within the administration, an escalation of conflict, and in general, an increase in the unpredictability of long-term results, as well as the alleged effects of "synergistic" individual policies that are almost 
impossible to coordinate (Offe, 1996). In our opinion, the above tends to increase in federal systems of government, where public administration is a complicated multi-organisational system functionally differentiated by departmental units and sectors, vertically and horizontally, so that the implementation of a policy does not concern a particular instance, but rather a group of instances.

Under these considerations, although complexity is present in different spheres of government tasks, it is in the social area where governance is more visible and therefore more necessary to articulate. Health policy, public security, and environmental or educational objects of our interest, to name a few, are related to problems requiring joint efforts between different organisations, not only within the same government, but other governments involved geographically and jurisdictionally. These are issues that know no boundaries, whose causes are interrelated, and mutually determined. In this sense, political-administrative maps are no longer useful to understand these issues, much less to contain them.

Education policy illustrates the difficulties in reaching joint public action on an issue that requires the intervention of different levels of management. Given the current structure of education systems in most Latin American countries, the development of a general policy is difficult because of interactions within and between educational governance at the central, sub-national, municipal, and school level, as well as between educational governance and its environment.

Defining the notion of governance of the education system requires us to consider a number of concepts associated with or contained in the idea itself, which help to clarify its essence. As part of this section some concepts that allow us to consider the conduct of educational systems as a research problem will be clarified. First, we refer to the category of education. The notion of a system has been present in various sociological conceptions of the educational phenomenon, which as a conceptual tool has helped to understand the complexity of the educational function and its internal and external relations.

According to Crozier (1969), the education system is a reflection of the social system, and is, at the same time, the essential medium perpetuated. Referring to the characteristic features of the bureaucratic system as adherence to rules, vertical relations, specialisation, and obedience as a cardinal virtue, Crozier notes that these patterns are arranged around the problem of social control and can only survive transmitted and strengthened by education. According to Luhmann's social theory, education is 
not only a constitutive, but also a constitutional system of the social system (Luhmann \& Eberhard, 1993). It seems important to recall at this point the view of Sander (1974), who believes that the use of the systemic perspective is not only possible, but also essential to understand and develop educational activities. By the nature of the functions assigned to it, education is one of the fundamental components of any social system in modern societies.

For our purposes, the words government and governance are also essential. They are doubtless interrelated, and one brings to mind the other. For example, the dictionary of the Royal Spanish Academy (2010) associates the word governance with the "quality of being governable" and equates the concept of governance with the "art or manner of governing" that has as its objective the achievement of a sustainable economic, social, and institutional development, and promoting a healthy balance between the state, civil society, and the market economy. The dictionary also defines governance as "the action and effect of ruling or governing".

Governance refers to a form of government more cooperative than the old hierarchical model, in which the authorities exercised sovereign power over groups and citizens who make up civil society. According to Mayntz, where policy networks are developed the government ceases to be the principal centre of society: "In policy networks, government and civil society are loosely coupled, and interaction within such networks produces a negotiated consensus which facilitates the formation of a policy, which at the time of its implementation encountered resistance" (Mayntz, 2001). Specifically, the governance of education systems has been defined in the "Declaration of Conception" of the Organisation of Iberoamerican States (1996) as the ability to meet the demands of the education of the school population and of society as a whole, as well as the ability to resolve internal conflicts that occur within the organisation. Thus the Declaration recognises the emergency issue of the governance of education systems in Latin America that has had various reforms to its credit by then.

It is worth noting that the governance of education was conceived together with the need to strengthen its systemic behaviour. Thus for Tenti the government assumes the notion of a system, i.e., something that has a consistency, a reality, and which is ruled; but also the idea that there are gifted actors of interests, projects, programs, resources, and strength to give direction and meaning to the system (Tenti, 2004). Another statement that accounts for the relevance of the systemic view of the effects of governance of education is made by Delors (1996), who says that future 
societies and the need to mobilise forces far beyond formal institutions confer a new role on public authorities. On the one hand, the visibility and legitimacy of the educational system must be ensured, thus ensuring the stability of the whole. Furthermore, it should encourage various associations to become more involved in education policy.

In this vein, the problem of steering education systems has to do with the fact that education is increasingly less like a system that has no centre from where it leads, the protagonists are increasingly more numerous and maintain the game of partnerships, steeplechase is increasingly complicated and in many cases polarised (Tenti, 2004). Meanwhile, Tedesco adds that governance of education systems should be placed in the broader context of the governance problems of society. There is ample evidence to justify this broader view; many phenomena occur outside the education sector but are within its scope (Tedesco, 2004).

Among the situations that have come to complicate the governance of education we wish to emphasise the fact that educational systems are currently fragmented, increasingly polycentric, and the actors who play a role in the field of education policy are more numerous because the traditional school community, professional associations, employers, unions, the media, international expert bodies, and, of course, local government bodies are added.

In the case of Mexico, we start with the assumption that educational federalism that was established by the National Agreement for the Modernisation of Basic Education has affected the governance of the education system, particularly the steering capacity of the national authority called the Secretariat of Public Education, which is responsible for setting objectives, strategies, and lines of action of general education policy. It is essential to contextualise the task of steering, noting that the system comprises more than 37 million students, 240,000 schools, and 1.6 million teachers (INEE, 2008). The system is organised federally and consists of 32 local education centres as subsystems.

\section{National Education Policy and Educational Federalism}

Once we have raised the issue of governance of the education system as a political, theoretical, and practical problem, we now turn to the meaning that the notion of a national education policy has in the context of the 
current model of organisation and functioning of education in Mexico. Understanding this model and the role the federal government has played through the Ministry of Education first requires us to present a general overview of the management steps that preceded it: devolution and decentralisation. To schematically illustrate the reform process that has been carried out in the Mexican educational system, and thereby put into perspective educational federalism as the operating scheme in force, we will use Table 1.

Table 1: Variants of the reform of the education system in Mexico

\begin{tabular}{|c|c|c|c|c|}
\hline \multirow{3}{*}{\multicolumn{2}{|c|}{$\begin{array}{l}\qquad 1921 \\
\text { Federal Government } \\
\text { Secretaría de Educación } \\
\text { Pública } \\
\text { Ministry of Public } \\
\text { Education (SEP) }\end{array}$}} & \multirow{3}{*}{\begin{tabular}{l}
\multicolumn{1}{c}{1983} \\
$\begin{array}{l}\text { Federal Government } \\
(\mathrm{SEP})\end{array}$ \\
$\begin{array}{l}\text { GOBIERNOS } \\
\text { ESTATALES }\end{array}$
\end{tabular}} & \multicolumn{2}{|c|}{1992} \\
\hline & & & \multirow{2}{*}{$\begin{array}{l}\text { Federal } \\
\text { Government } \\
(\text { SEP })\end{array}$} & \multirow{2}{*}{$\begin{array}{l}\text { State } \\
\text { Governments }\end{array}$} \\
\hline & & & & \\
\hline $\begin{array}{l}\text { Centralisa- } \\
\text { tion } \\
\text { (I) }\end{array}$ & $\begin{array}{l}\text { Deconcen- } \\
\text { tration } \\
\text { (II) }\end{array}$ & $\begin{array}{l}\text { "Decentralisation" } \\
\text { (III) }\end{array}$ & \multicolumn{2}{|c|}{$\begin{array}{l}\text { "Educational Federalism" } \\
\text { (IV) }\end{array}$} \\
\hline $\begin{array}{l}\text { Representa- } \\
\text { tion offices } \\
\text { of the SEP in } \\
\text { the states }\end{array}$ & $\begin{array}{l}\text { Delegations } \\
\text { of the SEP } \\
\text { in the states }\end{array}$ & $\begin{array}{l}\text { Coordinate Services of } \\
\text { Public Education in the } \\
\text { States }\end{array}$ & $\begin{array}{l}\text { Regulation } \\
\text { faculties } \\
\text { at national } \\
\text { level }\end{array}$ & $\begin{array}{l}\text { Regulation } \\
\text { faculties in } \\
\text { the state }\end{array}$ \\
\hline
\end{tabular}

Source: Covarrubias, 2000

Four main stages can be distinguished in the management of the education system in Mexico. The first one (I) corresponds to the phase of centralisation that began with the creation of the Ministry of Education in 1921, and with it the beginning of educational action on a state-wide scale. The performance of successive governments would be characterised by maintaining and expanding educational services. Along with the quantitative expansion of educational services intended to reach all regions of the country, a structure in which substantive decisions were defined and exercised from the centre of the country was consolidated.

Federal interference is considered a prerequisite of educational growth: only the national government could guarantee sufficient resources to expand enrolment, a goal linked to economic and social development. Referring to the centralised nature of this process, Aguilar notes that in the twentieth century, a post-revolutionary political system configuration and 
the need to modernise the social and economic life of the country emphasised the dominance of the federal government over the other branches of government (Aguilar, 1996). Claiming that centralisation is a natural tendency of federal systems, he adds that in the case of Mexican federalism this resulted in the supremacy of the federal government over the sovereignty of the states. Thus he argues that the dominance of federal power was the only way to make economic development compatible with the requirements of social justice, bringing about the expansion of the state apparatus to strengthen its intervention in the areas of social benefit. However, centralisation also brought about bureaucratic processes, problems of efficiency, and effectiveness of the administrative apparatus, as well as the quality, efficiency, and inequality of the educational services themselves.

The second stage (II) comprises what is known as deconcentration 19781982, and its history of explosive population growth and the spread of education, which resulted in a disorderly expansion of the educational system, the gradual and progressive loss of administrative control, as well as the deterioration of substance. The education system ended up favouring the more populated regions to the detriment of rural areas. There was an urge to curb the growing gap between different areas of the country and promote a more equitable distribution of educational opportunities. Through devolution, in 1978 the federal government established in each of the states of Mexico bodies called General Delegations, responsible to the Ministry of Education, assigning them all operational tasks with the respective powers of decision for the purpose that they were established, in accordance with the particular characteristics of the states. With deconcentration the decision-making power between levels and instances of the Secretariat itself was redistributed, and represented an earlier phase of education decentralisation that the government would try from 1982.

The third stage (III) spanned the period from 1982 to May 1992 and was known as "decentralisation". Its aim was to find a redistribution of power in a more balanced decision for the provision of services in the states; by the approach of making decisions where the services are provided; the possibility of greater involvement of the user community in defining needs to be met by work programs; as well as the relevance of learning through the participation of stakeholders in defining the curriculum. At the time, the intention to decentralise was reflected in the National Development Plan of 1983-1988, which stated that the decentralisation of basic education was a fundamental step to improving the efficiency and quality of educational action, and to encouraging community participation (Federal 
Executive Branch, 1983). Although this period is known as "educational decentralisation", in practice it was far from being a true redistribution of power between the federation and the states. Instead, it was decided to establish in each state structures called Coordinated Services of Public Education, by which it was sought to administer educational services through a scheme of shared responsibility between federal and local authorities. However, not only did the federal government not transfer services, but also its regulations became more stringent regarding an important aspect of the pedagogical repertoire and administrative faculties.

Finally, the fourth stage (IV) formally began in May 1992 with the signing of the National Agreement for the Modernisation of Basic Education and this was how educational federalism came about. To Moctezuma (1993), federalisation is qualitatively different than in other countries, where decentralisation has meant the fragmentation of a national system or the simple transfer of functions and resources. He states that in the case of Mexico, the federalisation of education strengthens the powers of the federal authority to ensure national unity, education, and participation of state governments in the operation of services. According to the official discourse on federalism, the paper should rethink education authorities at the central and local level; in the first case, to concentrate efforts on strengthening the capacity of national leadership, and in the second, to increase coordination between school work with authorities, institutions, and other sectors of the community (DOF, 1992).

In our opinion, educational federalism refers to two issues. The first is that federation transferred to state governments the administration of basic services and regular education. Another is that with the restricted operational responsibility of the federal government compared to that of the capital, the general regulation of the education system is confirmed to be within the substantive jurisdiction of the Ministry of Education. With this, there is a clearer picture of the powers divided between the federal and state level, a situation that did not occurr in the previous stage, where both levels appeared, at least in theory, as responsible for the operation of the service in each entity.

Today, 18 years of educational federalism have been implemented; the data suggest that this measure has not translated into better education as important problems of terminal efficiency and quality persist. Referring to this, Santizo Rodall (2009) argues that one of the main causes that have impeded the success of decentralisation in Mexico is that responsibilities were delegated, but not the means that would allow local authorities and school communities to take decisions they had been granted the power to take. 
It is also worth noting that the decentralisation of education in our country has been framed by a recurring economic crisis, which has led to the deterioration of the living conditions of a growing number of inhabitants. This has prevented the eradication of the problems of illiteracy, neglect, truancy, failure, and underachievement, despite the efforts of educational authorities. On the other hand, problems such as centralisation, bureaucracy, lack of educational modernisation, a strong presence of union interests, and poor formulation and implementation of policies affecting the management and operation of the educational system still limit the possibilities of solving issues that affect education.

However, decentralisation has also offered opportunities for education closer to the needs of communities and schools. Several states have conducted exercises at the regional level, regarding the design of educational policies, plans and programs of study, to promote new leadership by school managers, the impulse to work together, as well as the dissemination of project strategies to solve educational problems in school zones and schools (Calvo, 2002).

It is important to clarify that when we speak of educational federalism, we are not looking to criticise federalism as a mechanism of government; we are referring instead to the specific strategy of decentralisation in Mexico, the implementation of which has presented both disadvantages and opportunities.

After this brief review of the management periods of the education system, we are able to define the concept of the national education policy in the context of educational federalism in force today. For the purposes of this paper, we will define it as follows: a set of objectives, strategies, and action plans that deal with the conduct and development of the education system as a whole. A policy whose national character comes not only from the fact that it is promoted or conducted by the federal authority, but because it refers to a matter of principle that involves state and local authorities equally. Politics as a collective action involves the intervention of a large number of participants and is directly linked to the fundamental tasks of the Ministry of Education, in the sense that its role as a federal authority imposes responsibility on the subject in two aspects: one related to the overall conduct of the educational system, and another with the establishment of a framework for planning to be taken by local authorities. This guiding nature of the federal government has ample support in legislation across different systems. Article 3 of the Constitution of the Mexican United States, in addition to enshrining the right to education, makes education that is imparted by the state compulsory, free, and secular 
(DOF, 2002). For its part, the Education Act (DOF, 1993) in this constitutional provision to divide responsibility in the area of education, in Article 12 establishes the powers that correspond exclusively to the federal executive branch through the Ministry of Education. Among these are: Determining at the republican level plans and curricula for preschool, primary, and secondary education and teacher training, as well as for teacher training at the primary level;

Conducting the overall planning and programming of the national education system; and

Ensuring the evaluation of the national education system as well as establishing general guidelines for the evaluation that local authorities must perform.

Article 13 also sets out the powers that are the responsibility of the LEAs, highlighting the services that provide initial, basic, indigenous, special education, and teacher training.

Considering the nature and scope of responsibilities in the Mexican educational system, four levels of administration can be distinguished: 1) federal or central, 2) state or sub-national, 3) municipal or local, and 4) school. However, it should be noted that the municipal share is reduced to collaborating with the respective state government in the construction, maintenance, and improvement of school buildings and equipment. 


\section{Table 2: Levels of administration of the educational system in Mexico}

\begin{tabular}{|c|c|c|}
\hline Levels & Responsibilities & $\begin{array}{l}\text { Administrative } \\
\text { Structures }\end{array}$ \\
\hline \multirow{2}{*}{ 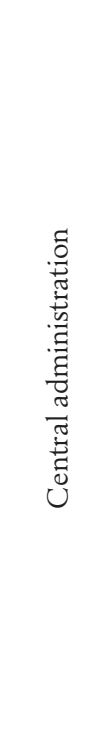 } & $\begin{array}{l}\text { Scope: National education system } \\
\text { General regulations of the education system; determin- } \\
\text { ing plans and curricula for basic education and teacher } \\
\text { training; setting educational requirements for initial } \\
\text { and preschool education; establishing the school cal- } \\
\text { endar; developing free textbooks; authorising textbooks } \\
\text { for primary and secondary education use; regulating } \\
\text { the national credit system, revalidation and equiva- } \\
\text { lence; performing the planning, programming, and } \\
\text { global evaluation of the education system; and exerting } \\
\text { the necessary powers to ensure the national character } \\
\text { of basic education and teacher training. }\end{array}$ & $\begin{array}{l}\text { Central Offices of the } \\
\text { Ministry of Public Educa- } \\
\text { tion (SEP) }\end{array}$ \\
\hline & $\begin{array}{l}\text { Scope: Capital of the country } \\
\text { Provision of services of initial, basic, and special ed- } \\
\text { ucation*. } \\
\text { *According to the transitional and final provisions of } \\
\text { the Education Act, until the transfer of these servic- } \\
\text { es to the Government of the DF is concluded, this } \\
\text { responsibility in the country's capital is assigned to } \\
\text { the SEP *) }\end{array}$ & $\begin{array}{l}\text { Federal Administration } \\
\text { of Educational Services } \\
\text { in the Federal District } \\
\text { (decentralised office of } \\
\text { the SEP) }\end{array}$ \\
\hline 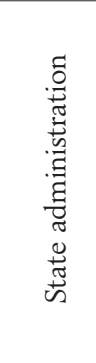 & $\begin{array}{l}\text { Scope: Federal entities } \\
\text { Administrative ownership in its territory; provision } \\
\text { of initial and basic education, and teacher training; } \\
\text { proposal of regional content to be included in the } \\
\text { plans and curricula; adjustment of the school calen- } \\
\text { dar for each school year; validation and granting of } \\
\text { equivalence to basic education studies and teacher } \\
\text { training; granting, denying and revoking permission } \\
\text { for individuals to provide basic education and teach- } \\
\text { er training. }\end{array}$ & $\begin{array}{l}\text { State Ministries of Edu- } \\
\text { cation or equivalent ad- } \\
\text { ministrative units. }\end{array}$ \\
\hline 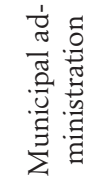 & $\begin{array}{l}\text { Scope: Local } \\
\text { Promotion and provision of educational services of } \\
\text { any type or form, participation in the maintenance } \\
\text { and provision of the basic public school team. }\end{array}$ & Municipalities \\
\hline 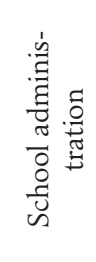 & $\begin{array}{l}\text { Scope: Schools } \\
\text { Direct provision of educational services }\end{array}$ & $\begin{array}{l}\text { School organisation. } \\
\text { Composed of directors, } \\
\text { teacher councils, teach- } \\
\text { ers, staff and supplemen- } \\
\text { tal educational services, } \\
\text { support and assistance to } \\
\text { education. }\end{array}$ \\
\hline
\end{tabular}

Source: Own analysis based on the General Law of Education (DOF, 1993) 
The repertoire and nature of the authority cited include those related to the planning of the educational system. The legal basis for this, in addition to Article 12 of the General Law of Education mentioned above, is formed by Article 21 of the Planning Act, which provides that the federal executive agencies should plan and conduct their activities subject to the objectives and priorities of national development planning (DOF, 1983). However, it should be noted that although the General Law attributes the overall planning of the educational system to the federal government, decentralisation forces us to rethink this role both in terms of its methods and its resources. By increasing the involvement of local authorities in the provision of services on the basis of educational federalism, education policy can no longer be considered an exclusive responsibility of the federal government.

Once the notion of the national education policy and the role of Ministry of Education as the federal authority have been defined, this indicates that this policy is formally expressed in the sectoral program, according to the aforementioned Planning Act, and should be harmonised every six years, which is the duration of the federal government in Mexico. For example, during the period covered by educational federalism, the following were prepared:

- Educational Development Program 1995-2000

- National Education Program 2001-2006

- Education Sector Program 2007-2012

The last program was created by the current government, i.e., the during the presidency of Felipe Calderón Hinojosa. That document expresses the objectives, strategies, and lines of action of federal departments and agencies belonging to this sector.

President Calderon (SEP, 2007) noted: "The Education Sector Program, like the rest of the sectoral programs, has been prepared as a starting point of Mexico's Vision 2030 and National Development Plan, and is the result of extensive consultation with stakeholders in the sector who have contributed diagnostic elements and action." He pointed out that it was formulated in accordance with the provisions of the Planning Act, and is also part of a strategy to promote the development of the country.

We conclude this section by pointing out that the Education Sector Program represents, for our purposes, the current expression of the process of change or evolution of education policy that we allude to in the title of our article, and it shows that with educational federalism, as a relatively uniform system regulated by a central authority, it transitions to a pluri- 
centric system, fragmented into 32 local educational subsystems. With these structures education policy is still the responsibility of the federal government.

This occurs through greater democratisation and political pluralism, which makes new governments at different levels emerge from opposition parties. This undoubtedly becomes a more difficult task for the government, given that consensus decisions should take into account the views of various political parties, social groups, and dissident groups with often conflicting projects. It should be noted that in 1989, an opposition party won the first governor position and ten years later there were as many as 11, including Mexico City as the capital. Six of these belong to the National Action Party, four to the Party of the Democratic Revolution, and one to an alliance between various parties (Espinoza, 2002). With this, the increasing presence of relatively autonomous political powers, which are not accountable to the central government but to their voters, introduces a new dynamic into the evolution of public policy in general and education policy in particular. With federalism, the formulation and implementation of education policy have become increasingly complicated. The presence of new actors and decision centres at a local scale requires more extensive and intense negotiations to articulate and get the required support for a course of action or reform. In this context emerges the problem of the governing capacity of the Mexican educational system and the meaning of the Education Sector Program 2007-2012 formulated by the Ministry of Education as a national ministry, as an expression of national education policy.

\section{The Problems of Articulating an Education Policy in Federalism}

As we have seen, since the signing of the National Agreement for the Modernisation of Basic Education in May 1992, the education policy has altered its course. The objectives, strategies, and targets previously considered national have begun to align with needs - and especially to suit the abilities - of each state. A number of tuning problems have arisen from this; education policy as it had been previously conceived has broken down. The priorities and targets set out in this document were mandatory only for units responsible to the Ministry of Education, and agencies grouped in the sector of the federal public service were coordinated by that agency. 
The process is certainly significant, because it leads to a sort of division of educational planning that loses cohesion. This is due not so much to LEAs assuming or diligently exercising devolved powers, but to factors associated with the fact that sub-national and local governments have their own traditions, "looks", ways of understanding or doing things. Furthermore, they have different administrative capacities to operate policies and programs, which is why dissimilar paths and achievements are recorded in each case (Covarrubias, 2006).

However, among the various factors that affect the governance of the education system, in this paper we focus on the problem of the structuring of political federalism. In this regard, we provide two types of evidence that seem significant. One is a series of testimonies of secretaries of education in different states of the Mexican Republic and Ministry of Education officials, expressed in a series of meetings called National Dialogues on Education Policy. And the second is a fundamental question: how periods of government are structured at the federal and local levels in Mexico.

In the first case, the meetings are not only illustrative as such, but also because these meetings enabled those responsible for education in the states to express problems of coordination between federal and local programs on the subject. To begin with, it would be appropriate to say that the information presented here was not exactly public disclosure; these are documents known as "executive summaries". In these documents, meetings are defined as small workgroups, which under a "strictly confidential mechanism" allow for the discussion of new scenarios for managing the Mexican educational system between Ministry of Education officials, their counterparts in the states and undersecretaries; and tasks of planning and coordination, as well as basic education and teacher training within the SEP (SEP 2003). Its objectives are given below:

- To create operational working groups between the Secretaries of Education of the various states and the Secretariat of Public Education.

- To confront the experiences and policies implemented by the various states, and on the basis of these evaluate alternatives.

- To carry out peer review to improve the education system strategy of each state.

State secretaries for education were divided into small groups which allowed for extensive discussion on the following topics: quality, equality, federalism, and financing. To this end, four regional working groups were organised as presented in Table 3. 
Table 3: Territorial competence of the four working groups

\begin{tabular}{|l|l|}
\hline Northwest Region & Northeast Region \\
\hline - Baja California & - Aguascalientes \\
- Baja California Sur & - Coahuila \\
- Chihuahua & - Durango \\
- Colima & - Hidalgo \\
- Jalisco & - Nuevo León \\
- Sonora & - San Luis Potosí \\
- Nayarit & - Tamaulipas \\
- Sinaloa & - Zacatecas \\
\hline Central Region & Southeast Region \\
\hline - Distrito Federal & - Campeche \\
- Morelos & - Oaxaca \\
- Michoacán & - Quintana Roo \\
- Guanajuato & - Tabasco \\
- Guerrero & - Veracruz \\
- Estado de México & - Yucatán \\
- Tlaxcala & - Chiapas \\
- Puebla & \\
- Querétaro & \\
\hline
\end{tabular}

Source: Authors

The topics were grouped into four areas: quality, equality, federalism and financing. The procedure used was to analyse the reports that account for the topics addressed and the agreements of each working group, in order to specifically identify statements regarding the need to improve coordination between the planning of the federal authority and the state authorities. In this regard, it is important to note that the issue was part of the agenda of four regional forums. The views or claims expressed by local officials on federal education by the Ministry of Education can be summarised in the following five points:

1. It is necessary to improve coordination between the national program and state education programs, in both directions, during both design and implementation.

2. It requires the institutionalisation of mechanisms for joint planning and coordination between the federal and local education authori- 
ties. There is a need for a collegial body in which the actors discuss what everyone wants to do and how this can be supported.

3. The national education program is formulated unilaterally and centralised, and the federal goals do not respond to local needs. This calls into question the contribution of federal projects to the quality of local education.

4. The national program imposes additional workloads on state authorities without providing adequate financial support. There is a perception among local officials that their states only provide resources for federal programs, so they will also review the financial needs of state programs.

5. States have little room to manoeuvre because of a chronic lack of funds, and those funds that are received should be allocated to the payroll as well as the realisation of federal programs in the federal entity.

The information presented exposed obvious similarities in the attitudes of those responsible for education at the state level with regard to the need to coordinate federal and state policies. Claims on financing were also numerous, but are not cited for reasons of space. Besides being tied to the problem of joint policies, they speak of the little room to manoeuvre that is available to the educational authorities at both the federal and local level if they wish to invest in new projects. State secretaries for education in the states of the Northeast Region asserted strongly that approximately $95 \%$ of the budget should be allocated to pay staff.

It is also worth noting that in December 2005 the first national meeting of the National Authorities on Planning and Educational Evaluation took place, during which it was decided that a proposal would be made to the National Council of Educational Authorities to create a permanent body to deal exclusively with issues related to educational planning. A few months later, on 3 April 2006, the Working Committee of Educational Authorities Responsible for Planning and Evaluation was formally established, "a deliberative and thematic instance", composed of those in charge of the principal areas of planning and evaluation of the secretariats and educational institutions of the states, and including members of the Planning and Policy Evaluation Unit of the Secretariat of Public Education (CONAEDU, 2006). This purpose is far from simple: to promote the coordination of planning the national education system.

The issues affecting the management of the federalised education system were also addressed by the National Conference of Governors (CONA- 
GO), created on 13 July 2002 as a space for dialogue and interaction between the heads of states and the executives of the Mexican federal government. From a review of the agreements reached at the various meetings of governors on the subject at hand, we consider it necessary to quote the following as specifically related to the coordination of education policy (Table 4).

Table 4: Coordination of education policy based on the agreements of governors

\begin{tabular}{|c|c|}
\hline MEETING & AGREEMENTS \\
\hline $\begin{array}{l}\text { XVII Regular meeting } \\
\text { held on June } 7,2004 \text { in } \\
\text { Villahermosa, Tabasco } \\
\text { (CONAGO, 2004). }\end{array}$ & $\begin{array}{l}\text { The proposal to hold a meeting with the Secretary of Ed- } \\
\text { ucation is approved, and the Secretaries of Education of } \\
\text { the States should maintain constant contact because the } \\
\text { information presented by the Commission differs from } \\
\text { what happens in some states on this issue. }\end{array}$ \\
\hline $\begin{array}{l}\text { XXIX Regular meeting held } \\
\text { on September 11, } 2006 \text { in } \\
\text { Nuevo Vallarta, Nayarit } \\
\text { (CONAGO, 2006). }\end{array}$ & $\begin{array}{l}\text { The Governor of the State of Zacatecas, Amalia García } \\
\text { Medina D., stressed the CONAGO manifest during the } \\
\text { meeting, so that the Federation expedite the delivery of } \\
\text { resources for education to the states. }\end{array}$ \\
\hline $\begin{array}{l}\text { XXXI Regular meeting } \\
\text { held on February 16, } \\
2007 \text { in Tlaxcala, Tlaxcala } \\
\text { (CONAGO, 2007). }\end{array}$ & $\begin{array}{l}\text { The Secretary of Public Education of the Federal Gov- } \\
\text { ernment, Josefina Vazquez Mota, proposed the establish- } \\
\text { ment of a joint educational agenda between the National } \\
\text { Conference of Governors and the Ministry of Education, } \\
\text { which would contain the following twelve points: } \\
\text { - Special education needs } \\
\text { - Training teachers and keeping them informed of latest } \\
\text { developments } \\
\text { - Participation of the school community } \\
\text { - Evaluation of educational quality } \\
\text { - Establishment of a national education information sys- } \\
\text { - tem } \\
\text { - Technological modernisation of education } \\
\text { - Comprehensiveness in upper secondary education } \\
\text { - Safety and reliability } \\
\text { - Infrastructure } \\
\text { - Certification of educational institutions } \\
\text { - Educational decentralisation } \\
\text { - Governance }\end{array}$ \\
\hline $\begin{array}{l}\text { XXXII Regular meeting } \\
\text { held on May 29, } 2007 \text { in } \\
\text { Puerto Vallarta, Jalisco } \\
\text { (CONAGO, 2007a) Source: } \\
\text { own analysis based on the } \\
\text { declarations from the } 36 \\
\text { CONAGO meetings. }\end{array}$ & $\begin{array}{l}\text { Coordinator of the CONAGO Education Commission is } \\
\text { authorised to meet with the Secretary of Finance to re- } \\
\text { view budgetary aspects, highlighting the current lack of } \\
\text { resources for infrastructure and to cover basic needs. }\end{array}$ \\
\hline
\end{tabular}

Source: Author's own summary based on the declarations from the 36 CONAGO meetings. 
As a result of the proposal made by the Minister of Education, Josefina Vazquez Mota, at the XXI regular meeting of the CONAGO, as can be seen in the table above, a national meeting of the Secretaries of Education took place in Saltillo, Coahuila, on 26 and 27 April 2007. According to the official report (CONAGO, 2007), the discussions that took place on the subject of educational federalism focused on "governance and financing, and the coordination between the three levels of government." At the meeting, the revision of the National Agreement for the Modernisation of Basic and Normal Education of 1992 was also discussed and the development of a new National Agreement was proposed. Among the most significant points to be discussed, the following were mentioned:

- Extension of the Agreement to all levels of education, fostering structural reform so that all levels of education are integrated;

- Redefinition of the responsibilities for distribution, allocation, and use of financial resources from the three levels of government, provision of alternatives to compensate for the existing financial deficit;

- Provision of contents, materials, and assessments to improve educational quality;

- Expansion of services and educational infrastructure to ensure universal coverage of education; and

- Promotion of the participation of parents and other stakeholders in the public, private, and social spheres in the educational process and its improvement.

It is now time to refer to the second type of evidence, which, in our opinion, has to do with the root cause of disorder and incoherence of the actions of the Mexican government regarding major social issues such as education. The many gaps result from the asynchrony between cycles of activity of governments (federal and national) and present a structural origin of major inconsistencies between national (federal-level) and local (state-level) planning.

As noted in Section 1, where it is suggested that the government education system is a complex task, the education system does not operate in a vacuum. In the case of Mexico, the articulation of problems to which we refer must be placed within the framework pointed out by Aguilar (2010), namely that today a critical issue in the operation of government is its fragmentation and incoherence. He argues that the Mexican State is a constellation of divergent self-referential political organisations. His view is the breakdown of concepts, approaches, practices, and priorities. 
For our part, we would add that education policy is a textbook example of this.

As is shown in Table 5, legislatures of only five of the 32 states coincide with the cycle of the central government: Chiapas, Mexico City, Guanajuato, Morelos, and Tabasco. The remaining 27 states should develop their programs taking into account two different national education programs. For example, in the case of Aguascalientes, the "incoming state government" must develop its planning taking into account the guidelines of a "projection federal government." The table also shows the political affiliation of governments. As can be seen, the ruling party in the federal government is the National Action Party (PAN), while the opposition parties are the Institutional Revolutionary Party (PRI) and the Party of the Democratic Revolution (PRD).

This largely explains the concern expressed by the former Secretary of Basic and Normal Education, Lorenzo Gomez-Morin in the sense that "... there are states that built their policy with a national plan, and if there was a national change, they would favour another (national) program above" (CONAEDU, 2003).

Table 5 : Periods of Government and Political Map of Mexico

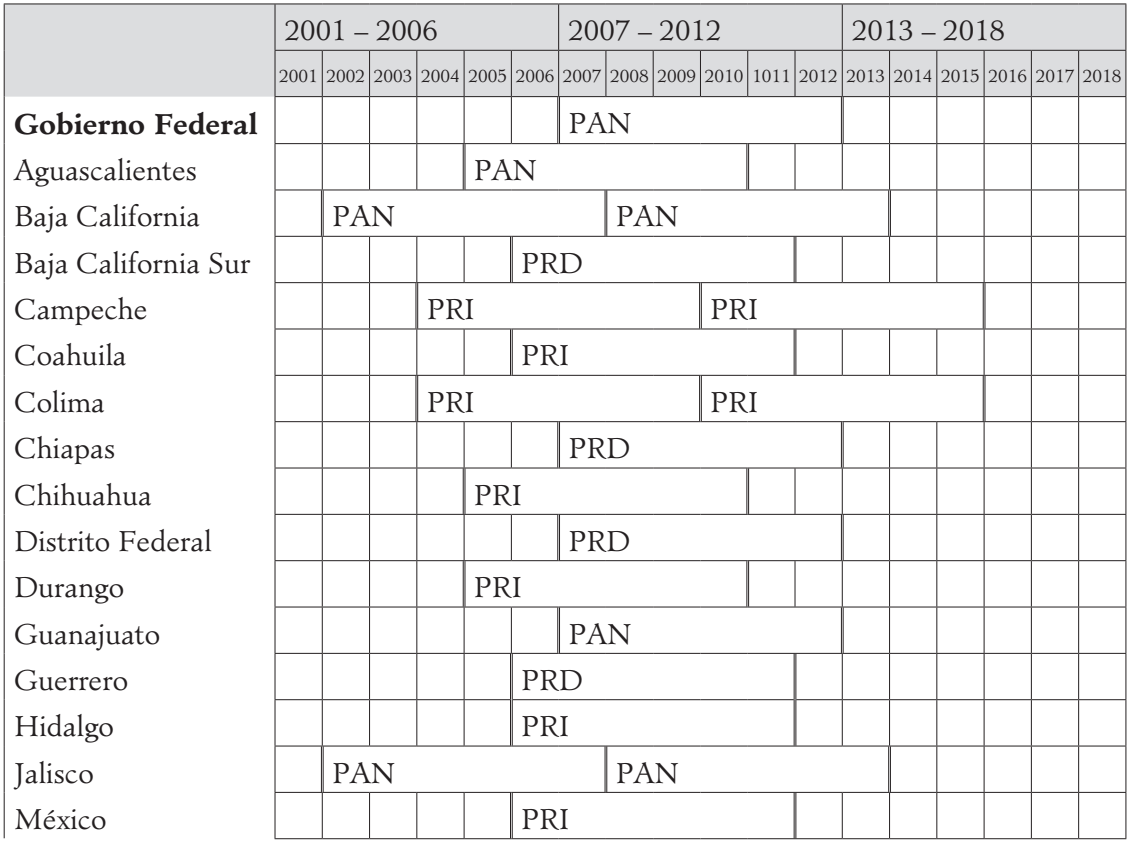




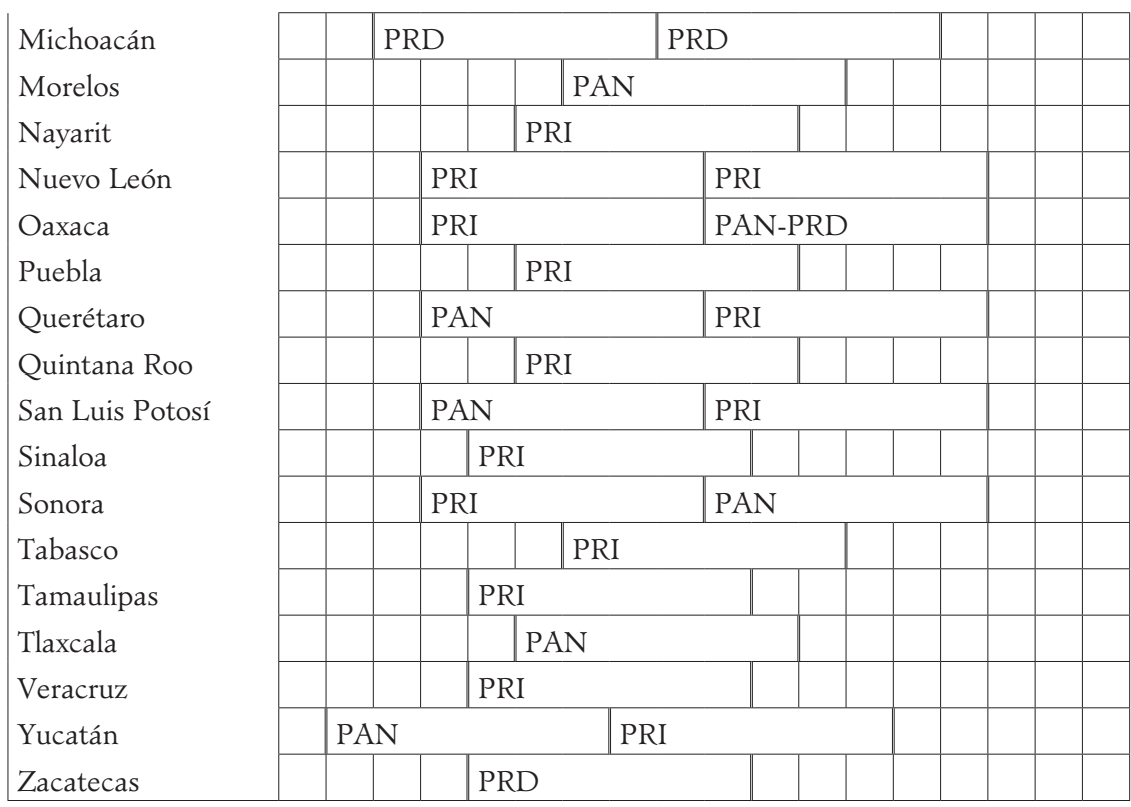

Tags: Institutional Revolutionary Party (PRI). National Action Party (PAN). Party of the Democratic Revolution (PRD).

Source: Authors

If we look at things in more detail, we can realise that besides lapses or discontinuities caused by multiple bottlenecks, in the first year of the federal government there is a lack of national planning. It should be noted that according to Article 21 of the Planning Act, six months are stipulated for the adoption of the National Development Plan (DOF, 1983). And virtually the remaining six months of the first year of management are intended for the development of the respective sectoral programs. This is fairly simple, but illustrates the problem of mismatch between periods or cycles of government in Mexico.

The federal government changes result in a cascade of transitions at the local level. Where there are risks of longer transitions due to incoming authorities, it should be also expected that the federal government will release the National Development Plan, especially the various sectoral programs that guide the formulation of own plans and programs. This speaks of a dispersion of effort; significant opportunity costs are generated.

All this should lead us to wonder about the implications of the lack of harmony in government periods, in terms of planning the overall development of the country as well as in individual states, especially in areas 
such as education, which is a long-term policy. It is very difficult to align policies when most states must do their planning with sectoral programs in two different federal administrations as reference points. Referring to the need to carefully review the Mexican political system to detect dysfunctions, Francisco Casanova (2008) states that it is convenient to rearrange the election and periods of government of the country to improve governance and efficiency calendars.

In addition to the gap between the design of national policy and state policies, the chronic shortage of resources reinforces the fact that the SEP enjoys a margin of discretion to make restrictive decisions regarding normative elements of the education system. To illustrate this, it is worth noting that Mexico spends $5.7 \%$ of its national education revenue, which makes this percentage the highest rate of investment in OECD countries (21.7\% of total government expenditure compared to an average $13.3 \%$ in the OECD); however, in absolute numbers, spending per pupil remains very low. For example, Mexico spent $\$ 2,111$ per pupil in primary education compared to an average of $\$ 6,741$ in the OECD, and $\$ 2,236$ per pupil in secondary education versus an average of $\$ 8,267$ in the OECD (2010). In addition to the limited budget, over $90 \%$ of expenditure is consumed by the payroll costs (OECD, 2010).

If the same structure of spending continues, i.e., if current spending increases, it is not clear where to go for additional funding which would be earmarked for special programs such as quality, equity, and efficiency of education, and possible development in the desired direction greatly depends on this.

In short, the impact of multiple transitions of government is not easy to measure; we speak of measuring the medium- and long-term impact of policies, but as we have already noted, the lags of education policy seriously damage the dynamics and efficiency of government in this important area.

\section{Sectoral Education Program Versus National Education Policy}

In this section we will make some clarifications that will help us answer if, given the conditions mentioned above, the Education Sector Program and the National Policy on Education, are equivalent issues. To begin with, we must say that although broadly the concept of a sector can be understood to mean all public and private organisations within a society 
that provide a good or service, in the field of public administration a sector refers specifically to a body which has been charged with fulfilling a function or purpose that is inherent to the state. Sectorisation represents the delineation of roles and responsibilities in homogeneous groups of activity to clarify responsibilities, avoid the duplication of functions, and enable government decisions to flow efficiently.

In this sense, the policy of a sector can be defined as behaviour that assumes the government intended to effectively articulate the actions of the agencies and entities which contribute to the implementation of the same subject, under the coordination of a ministry legally responsible for setting the guidelines and guidance necessary to give coherence to government policies and thereby avoiding a conflict of responsibility within the same sector. Thus, the activities of the cluster of organisations that make up a sector gravitate singularly towards a character who formally has the authority and responsibility to formulate sectoral policy: the minister or secretary of the branch or sector.

In a federal system, if the government has adopted this form of organisation, this leads to the existence of sectors at the federal, state, and municipal level. Of course, in the case of the federal government, unlike at the local level, sectors are characterised by their usual activities which have implications for the country as a whole. In this sense, the formulation of sectoral policy by a federal ministry is a responsibility linked to the notion of a national policy, whose formal expression is ordinarily contained in sectoral plans or programs which by their nature and sphere of influence "govern" the set of sectoral and institutional programs of local character.

These details are useful for determining where the notion of national education policy is compared with the Education Sector Program 2007-2012. It must be said at the outset that they are not equivalent issues; the first refers to the education system as a whole and it is intended for three levels of government. Although the National Sector Program also addresses its objectives, lines of action, and goals towards the national education system, it only commits, in the strict sense, the administrative units of the Ministry of Education and the organizations it coordinates. The same happens in each state, where local authorities are, at first instance, governed by their own sector programs.

Similarly, the very name of the Sector Program appears to account for a kind of waiver or recognition by the federal government, providing diminished possibilities of steering the national education system. The sectoral nature of the program is in contrast to the designation given to previous programs mentioned above. 
What appears to be only a matter of form becomes meaningful if we take into account the few references therein: decentralised management and administration of the education system. For example, the National Education Program 2001-2006, has devoted one of its three parts to the management of the education system.

\section{Conclusion}

After two decades of education system reforms in several Latin American countries, the issue of governance of the education system as a theoretical, political, and practical problem emerges clearly. And since this system does not operate in a vacuum, it is an issue that must be seen in the broader context of the governance problems of society as a whole. There is ample evidence to justify a broader perspective, as increasingly phenomena occurring outside the education system enter its scope.

As we have seen, the problem of steering education systems has to do with the fact that education is becoming increasingly less like a system; it lacks a single centre from where it is governed, the actors are increasingly numerous and complicated, and in many cases the relationship is more highly polarised.

In Mexico the National Agreement for the Modernisation of Basic Education of May 1992, which transferred basic education services to the states, has seen education policy lose cohesion. The compact policy, which had for decades been structured vertically, began a process of dismantling.

Among the main reasons we mention the lack of responsibility of the federal government. Decentralisation was used to take a share of responsibilities in which, as if it were a hydraulic movement, one level of government receives what the other loses. As a result, mechanisms that would allow joint efforts of government levels were neglected.

No less important is the way periods of government are structured in the Mexican state. As has been documented, it is a substantive issue that limits the structuring of political federalism. The gap between government cycles at the federal and local level is the origin of the problems of fragmentation and inconsistency in education and in other important areas of public policy.

Against this, a realistic goal is to build long-term comprehensive policies to enable synchronisation and rebuild the unity of state action in education, thereby reducing the numerous lapses that affect action in this field. 
A disordered, dispersed state is ineffective even when resources become available, and formally restrains power. New trends in governance and public administration appear to be directed at the reconstruction of the lost unity of the state structure and action.

In this sense, the claim of a systemic and comprehensive vision of the educational task in our country will be required at the eventual risk of further fragmentation of the educational system. This approach turns out to be significant for purposes of studying not only the subject but also its management. Today, as federalisation gives rise to a larger number of institutions and actors involved in educational policy, a vision that recognises the existence of different levels of action and the importance of their working together becomes more necessary.

The segmentation of the educational system as a side effect of decentralisation may lead to the loss of an essential global perspective for decision-making, both state-wide and nationally, if it is not taken into account that education issues and even their solutions exceed jurisdictions and capacities.

In short, the development of this analysis is expected to provide elements that will help the reader think more clearly about the problems of disarticulation affecting public policy in Mexico. It is a topic that so far has not aroused much interest among specialists and academics. However, in the federal state structure it is a factor that prevents an orderly, coordinated, and effective response to the problems that affect us all.

\section{References}

Aguilar, L. (1996). The Mexican federalism operation and tasks. In A. Hernández (Ed.), Towards a New Federalism? (pp. 109-151). Mexico City, Mexico: Colegio de México, Fondo de Cultura Económica.

Aguilar, L. (2010). The fragmented state. Reforma Newspaper, Mexico City, Mexico., February 24.

Calvo, B. (2002). Introduction. In B. Calvo, M. Zorrilla, T. Guillermo \& S. Conde. School supervision of primary education in Mexico: Practices, challenges and reforms (pp. 21-41). France, Paris: UNESCO.

Casanova, F. (2008). A labyrinth without Minotaur. In E. Torres, \& P. Juan de Dios (Eds.), Transition and new institutions in Mexico (pp. 27-61). Mexico City, Mexico: School of Advanced Studies UNAM, LAT-NET, IAPEM.

CONAEDU (2006). According to the National Council of Educational Authorities for the formation of the Working Committee of Educational Authorities Responsible for Planning and Evaluation. Mexico, Campeche: Ministry of Education. 
CONAEDU (2003). National dialogue on education policy. Acta Northwest region. Mexico, Culiacán: Ministry of Education.

CONAGO (2002). Declaration of the second ordinary meeting of the National Governors' Conference. Mexico, Pachuca: Technical Secretariat of the CONAGO.

CONAGO (2004). Declaration of the fifteenth regular meeting of the National Governors' Conference. Mexico, Victoria: Technical Secretariat of the CONAGO.

CONAGO (2004). Declaration of the seventeenth regular meeting of the National Governors' Conference. Mexico, Villahermosa: Technical Secretariat of the CONAGO.

CONAGO (2006). Declaration of the twenty-ninth regular session of the National Governors' Conference. Mexico, Nuevo Vallarta: Technical Secretariat of the CONAGO.

CONAGO (2007). Declaration of the thirty-first regular meeting of the National Governors' Conference. Mexico, Tlaxcala: Technical Secretariat of the CONAGO.

CONAGO (2007a). Declaration of the thirty-second regular session of the National Governors' Conference. Puerto Vallarta: Technical Secretariat of the CONAGO.

Covarrubias, M. (2000) Federalism and reform of the national education system. Mexico City, Mexico: National Institute of Public Administration.

Covarrubias, M. (2006). Coordination of education policy in the federal system. Assessment of basic education in Mexico. Mexico City, Mexico: National Autonomous University of Mexico.

Crozier, M. (1969). The bureaucratic phenomenon. Buenos Aires, Argentina: Routledge.

Delors, J. (1996). The Learning: The Treasure. Madrid, Spain: UNESCO-Santillana.

DOF (2002). Political Constitution of the Mexican United States. Mexico City, Mexico: Official Journal of the Federation.

DOF (1993). General Law on Education. Mexico City, Mexico: Official Journal of the Federation.

DOF (1983). Planning Act. Mexico City, Mexico: Official Journal of the Federation.

Espinoza, A. (2002). Political and local governments in Mexico: Alternation. Sociological Studies, 1, 67-89.

Granados, O. (2004). Education in Mexico: Spend more or spend better? Mexico City, Mexico: ITESM.

INEE (2008). Educational panorama of Mexico. Indicators of national education system. Mexico City, Mexico: Secretariat of Public Education.

Luhmann, N. \& Eberhard K. (1993). The education system (Problems of reflection). Mexico, Guadalajara: University of Guadalajara, Universidad Iberoamericana, Western Institute of Technology and Higher Education.

Mayntz, R. (2001). The state and civil society in modern governance. Journal of CLAD Reform and Democracy, 21, 1-8.

Moctezuma, E. (1993). Public education faces new realities. Mexico City, Mexico: Fondo de Cultura Economica. 
OEI (1996). Statement Conception of the Organisation of Ibero-American States. Conception: Organisation of American States.

OECD (2010). Education at a glance. Paris, France: OECD.

Offe, C. (1996). Modernity and the state: East, west. Cambridge, UK: Polity Press.

Federal Executive Branch (1983). National Development Plan 1983-1988. Mexico City, Mexico: Graphical Factories of the Nation.

RAE (2010). Dictionary of the Spanish language. Madrid, Spain: Royal Spanish Academy.

Sander, B. (1974). The educational organisation as a social system. Education, 68/69, 7-23.

Santizo, C. (2009). Schools and social capital in Mexico. Metapolítica, 64, 56-60.

SEP (1992). National Agreement for the Modernisation of Basic Education. Mexico City, Mexico: Secretariat of Public Education.

SEP (2003). National dialogues on education policy. Minutes and executive summary. Mexico City, Mexico: Secretariat of Public Education.

SEP (2007). Education Sector Programme 2007-2012. Mexico City, Mexico: Secretariat of Public Education.

Tedesco, J. C. (2004). Prologue. In Tenti, E. (Ed.). Governance of education systems in Latin America (pp. 11-13). Buenos Aires, Argentina: International Institute for Educational Planning IIEP - UNESCO.

Tenti, E. (2004). New governance problems of education in Latin America. In Tenti, E. (Ed.). Governance of education systems in Latin America (pp. 45-64)., Buenos Aires, Argentina: International Institute for Educational Planning IIEP - UNESCO.

DECENTRALISATION AND GOVERNANCE OF THE EDUCATION SYSTEM IN MEXICO

\section{Summary}

The purpose of this paper is to present an overview of the progress of a little more than two decades of political decentralisation in Mexico, through so-called "educational federalism". The Agreement for the Modernisation of Basic Education in 1992 was a turning point in the bistory of education in Mexico, because it represented the first attempt at comprehensive reform in the sense that, in addition to curricular reform and the promotion of social participation, it comprised the overall redesign of the organisation and management of the education system. Our analysis aims to show the dislocation suffered by the national education policy due to the lack of coordination between the actions of different levels of government. We do not intend to argue against federalism as a system of 
political organisation, but to draw attention to the concrete experience of educational decentralisation in Mexico, and how the advantages of decentralisation can be undermined by shortcomings in its design and implementation.

Keywords: decentralisation, educational federalism, comprehensive reform, social participation, education system, coordination

\section{DECENTRALIZACIJA I UPRAVLJANJE OBRAZOVNIM SUSTAVOM U MEKSIKU}

\section{Sažetak}

Rad nudi pregled razvoja političke decentralizacije u Meksiku u trajanju nešto više od dva desetljeća, u okviru tzv. »obrazovnog federalizma«. Sporazum o modernizaciji osnovnog obrazovanja iz 1992 ključni je trenutak u povijesti meksičkog obrazovnog sustava jer predstavlja prvi pokušaj sveobubvatne reforme. Osim kurikularne reforme i poticanja društvene participacije sporazum također podrazumijeva potpuno preoblikovanje ustroja obrazornog sustava i načina upravljanja njime. U radu se nastoji prikazati raskorak u nacionalnoj obrazovnoj politici do kojega dolazi zbog nedostatka koordinacije izmedu poteza različitih razina vlasti. Ne namjerava se osporavati federalizam kao politički sustav, već se želi opisati specifično iskustvo sobrazornom decentralizacijom u Meksiku, i pojasniti kako prednosti decentralizacije mogu umanjiti nedostatci u oblikovanju i implementaciji.

Ključne riječi: decentralizacija, obrazovni federalizam, sveobubvatne reforme, društvena participacija, obrazovni sustav, koordinacija 